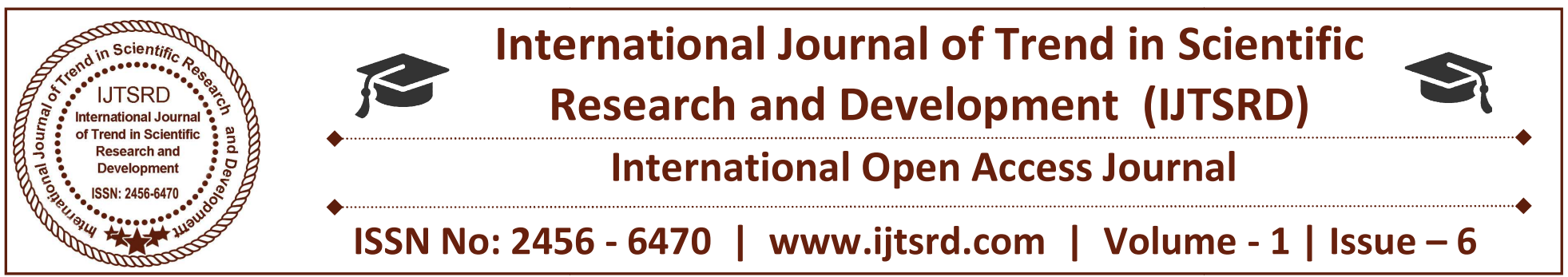

\title{
Comparison of Physicochemical, Nutritional and Sensory Aspects of Ghee obtained from Different Species
}

\section{Kapadiya Dhartiben B.}

Dairy Chemistry Department, Sheth M.C. College of Dairy Science Anand, Agricultural University, Anand

\section{Aparnathi, K.D.}

Dairy Chemistry Department, Sheth M.C. College of Dairy Science Anand, Agricultural University, Anand

\section{ABSTRACT}

Ghee is a class of clarified butter that originated from the Indian subcontinent; and is commonly used in South Asian and Middle Eastern cuisines, traditional medicine, and religious rituals. Ghee is important part of human diet. It also gives longer shelf life compared to other food product. Now days, people have interested in products obtained from species other than cow and buffalo to get more health benefits. Physicochemical, nutritional and sensory aspects of ghee obtained from different species varied among each other due to the varied composition of milk. Due to difference in the milk composition of varies species; these affect physicochemical, nutritional and sensory aspects of different species. Variation of this aspects affect the consumer's preference, benefits on human health from ghee of varies species and also helps to people who wanted to check adulteration in ghee.

\section{INTRODUCTION}

Ghee is clarified butterfat, usually prepared from cow milk, buffalo milk or mixed milk (Rajorhia, 1993). Ghee is manufactured by direct heating of cream or butter churned out of fresh or ripened cream or dahiobtained by fermentation of milk with bacteria native to milk or selected starter cultures (Srinivasan, 1976).Ghrita (ghee) was produced in ancient India as far back as 1500 BC (Achaya, 1997). Ghee is often used as a synonym for different dairy products, e.g. clarified butter (Kumar and Singhal, 1992), butterfat (Singh and Ram, 1978), Indian butteroil, butteroil, anhydrous milkfat (Sserunjogi and Roger, 1998) and Indian ghee (Kumar and Singhal, 1992).

Some other products related to ghee are samna (Aboudonia and El-agamy, 1993), meshho (an Assyrian non-perishable milkfat) (Abdalla, 1994). Ethiopian indigenous ghee (Bekele and Kassaye, 1987), samin (Hamid, 1993), roganin Iran (Urbach and Gordon, 1994)and samuli (Sserunjogi and Roger, 1998). Most other definitions of ghee are quite ambiguous and often lack universal applicability. Various agencies viz. IDF (1977), Codex Alimentarius (1997),Agmark (1988) have defined ghee and its requirements.According to FSSAI (2011), ghee means the pure clarified fat derived solely from milk or curd or from desi (cooking) butter or from cream to which no colouring matter or preservative has been added. The standards of ghee produced in a State or Union Territory have been specified for BR reading, RM value. Ghee chemically may be defined as complex lipids of triacylglycerol, together with small quantity of free fatty acids, phospholipids, sterols, hydrocarbons, carbonyl compounds, fat soluble vitamins ( $\mathrm{A}, \mathrm{D}, \mathrm{E}$, and $\mathrm{K}$ ), carotenoid pigments, moisture and traces of elements like copper and iron. On an average ghee contains $99.0-99.5 \%$ fat and less than $0.5 \%$ moisture.

\section{Physicochemical Aspects}

Physical properties of oils and fats are important criteria for judging their quality and have also been used to determine their purity (Hazraet al., 2017). Physical and chemical constants have been derived for the characterization of the types of component fatty acids present in milk fats. Several physical methods can be used to check the purity of ghee on the basis of various physical properties such as 
melting point, solidification point, BR reading, refractive index (Kumaret al., 2016). The average size of fat globules in milk of camels, cows, buffaloes, sheep, and goats is presented in Table 1. The largest diameter of fat globules is found in buffalo milk, whereas the smallest is in camel milk. Generally, camel, sheep, and goat milk fat globules are smaller in size compared to those of buffalo and cow milk. Therefore, these milks have poor creaming properties (Park and Haenlein, 2006; Kumar et al., 2015).

\section{Table 1: Average Size of Milk Fat Globules of Different Species}

\begin{tabular}{|l|c|}
\hline \multicolumn{1}{|c|}{ Species } & Diameter (microns) \\
\hline Camel & $2.00-3.93$ \\
\hline Cow & $3.00-4.50$ \\
\hline Buffalo & $4.07-7.50$ \\
\hline Goat & $2.57-3.25$ \\
\hline Sheep & $3.02-3.14$ \\
\hline
\end{tabular}

Parmar (2013) compared various physicochemical properties of cow, buffalo and camel ghee viz. melting point, solidification point,BR reading, refractive index, Reichert Meissl (RM) and polenskevalue (PV), saponification value, free fatty acid and iodine value. He found higher melting point, solidification point, refractive index, saponification value and iodine value whereas lower amount of free fatty acid, RM and PV value in camel milk ghee as compared to cow and buffalo milk ghee is probably because camel milk fat contains a lower amount of short chain fatty acids $\left(\mathrm{C}_{4}-\mathrm{C}_{12}\right)$ and a higher amount of long chain fatty acids $\left(\mathrm{C}_{14}-\mathrm{C}_{22}\right)$.

The compositions of fatty acids in camel, buffalo, sheep, and goat milk were reported by Park and Haenlein (2006). They reported that marked variations found among the four species. Compared to other species, camel milk fat is higher in iodine value, acid value and melting point, but lower in refractive index, Reichert Meissl, Polenske, and saponification values. This reflects its higher content of long-chain fatty acids $\left(\mathrm{C}_{14}-\mathrm{C}_{18}\right)$, and lower content of short chain fatty acids $\left(\mathrm{C}_{4}-\mathrm{C}_{12}\right)$. Camel milk fat had higher proportions of unsaturated fatty acids compared with other species, which may be the main reason for the waxy texture of camel milk fat. An appreciable amount of the essential fatty acid linoleic is found in camel and buffalo milk fatsby Park and Haenlein (2006).
Softening point, Melting point and Iodine value of cow, buffaloand goat ghee have been reported by Ramesh and Bindal (1987). The average softening point of cow, buffalo and goat ghee were 33.4,34.0 and $29.1^{\circ} \mathrm{C}$ respectively. The average melting point of cow, buffalo and goat ghee were 34.1, 36.1 and $28.9^{\circ} \mathrm{C}$ respectively. The average iodine value of cow, buffalo and goat ghee were 35.4, 31.4 and $33.3^{\circ} \mathrm{Crespectively.}$

Marked variations in physicochemical constants and fatty acid compositionamongst four species viz. cow, buffalo, goat and sheep milk fat have been reported byseveral authors (Park and Haenlein, 2006; AlKhalifah and Al-Kahtani, 1993, Sharma, 1981).Wayual et al.(2006)determined the fatty acid compositions of ghee made from camel's, goat's milk in Mandera, north eastern Kenya and found that camel milk ghee contained nutritionally adequate proportions of medium-chain fatty acids $\left(\mathrm{C}_{10-14}\right)$ $(19.9 \%)$. Goat milk ghee had higher proportions of short chain fatty acids $\left(\mathrm{C}_{8-10}\right)(14.5 \%)$. Compared to buffalo, goat and sheep, camel milk fat is higher in iodine value, acid value and melting point, but lower in refractive index, Reichert Meissl, Polenske, and saponification values Park and Haenlein, (2006).

Goat milk has a unique characteristic in the lauric: capric fatty acid $\left(\mathrm{C}_{12} \mathrm{C}_{10}\right)$ ratio, where it has a significantly lower ratio than cow milk (0.46 vs. 1.16$)$ (Iverson and Sheppard, 1989).There are no significant differences in the unsaponifiable matter of milk fat and acid value between goat and cow milks. However, goat milk has higher iodine values than cow milk, indicating that goat milk fat contains higher unsaturated fatty acids than the cow counterpart.

Saponification value is higher and refractive index is slightly higher in cow milk than in goat milk. Some interesting differences are found in the Reichert Meissl value and the Polenske value between goat and cow milk. Goat milk has higher Reichert Meissl value and lower Polenske value than cow milk, suggesting that goat milk fat contains higher soluble volatile fatty acids and lower insoluble volatile fatty acids than cow milk fat(Anjaneyulu et al., 1985).

\section{Nutritional Aspects}

Fat is a concentrated source of energy that provides $30-40 \%$ of dietary calories in developed countries. Fat imparts palatability to food, serves as a vehicle for fat-soluble vitamins $\mathrm{A}, \mathrm{D}, \mathrm{E}$ and $\mathrm{K}$ and supplies essential fatty acids. The digestion products of fats, along with endogenously synthesized lipids, provide a 
diverse group of molecules that play a critical role in multiple metabolic processes.Lipids are vital components of cell membranes and take part in many inter- and intra-cellular signalling cascades. Lipids have multiple forms and functions, including vitamins and steroid hormones that are involved in many metabolic processes (Parodi, 2004).

Conjugated linoleic acid (CLA) that occurs in high concentrationsin milkfat, has been recognized as an anticarcinogen, and its anticarcinogenic effect has beendemonstrated in several animal models (Chin et al., 1992).Anincrease in the CLA content of mixed (cow and buffalo) milkfat from base level of5-6 mg $\mathrm{CLA} \mathrm{g}^{-1}$ fat up to $1.0 \%$ was observed in the desighee due to fermentation. Also, the CLA content of gheecan be increased up to 5-fold from the base level, byincreasing the temperature of clarification from 110 to $120^{\circ} \mathrm{C}$ (Aneja and Murthi, 1991). CLA content of cow, goat and sheep milk fat were also varied (Tamine, 2009).

Ghee has been reported to contain $0.3-0.4 \%$ cholesterol (Nathet al., 1996). Nathet al. (1996) showed that mixed (cow+buffalo) ghee manufactured and stored under normal conditions did not contain COPS. The fat of goat milk is more digestible than that of the cow milk because the fat globules in goat milk are much smaller and have a greater surface area and lipases in the gut are supposedly able to attack lipids more rapidly. caproic, caprylic, capric acids and other medium chain fatty acids have been used as a treatment of malabsorption syndrome, coronary diseases, premature infant nutrition, intestinal disorders and gallstone problems (Jooyandeh and Aberoumand, 2010).

The consumption of goat milk reduces total cholesterol levels and the LDL fraction because of the higher presence of medium chain triglycerides (MCT) (36\% in goat milk vs. $21 \%$ in cow milk). They could also be used in a geriatric diet (Raynal-Ljutovacaet al., 2008).

Both goat and cow milk fat contain adequate amounts of essential fatty acids for human infants. Goat milk has much higher glycerol ethers than does cow milk, which appears to be important for the nutrition of the nursing newborn. Buffalo milk fat contains gangliosides which are not present in cow milk fat. The gangliosides of buffalo milk fat have antiinflammatory activity (Ahmad et al., 2013). The study carried out on 48 N-Mary male Syrian mice by Mohammadi and Azizi (2015) to compare the effect of different nutritious fats on expression ofapoB protein and showed that cow ghee increases expression of intestinal apoB48 compared to Sheep ghee. This ApoB is a component of all atherogenic or potentially atherogenic particles. Increase in the concentration of apolipoproteins B (apoB) is one of the major risk factors for coronary heart disease (CHD). Sheep ghee was proven as a protective fat against apoB48 concentration.

In ayurveda, cow ghee 'amrita'(nectar) is considered the natural oil for all internal body mechanisms. It had several health benefits such as slows the aging process, enhances the body immune system, facilitates the bowel movement, improve the health of the teeth \& gums, prevent chronic cough \& disorders of eyes, As a bath oil and an exquisite facial moisturizer (Mahakalkaret al.,2014).

\section{Sensory Aspects}

The colour of cow ghee varies from deep yellow to straw yellow while that of buffalo is white with a characteristic greenish tinge (Achaya, 1997; Bharwadeet al., 2017). Camel ghee's physical structure should consist of a mixture of higher softening point fats in crystalline form dispersed in the liquid lower softening point fats and this gives the ghee a somewhat granular appearance(Ruegg and Farah, 1991).Singh and Gupta (1982) reported that the majorityof ghee prepared from goat milk cream ripened withlactic starter culture was greenish white, while all cowmilk gheewas bright yellow in color. The colour and appearance score of ghee prepared from camel milk was significantly lower compared to ghee prepared from cow milk as well from buffalo milk (Parmar, 2013).

Ghee is greatly valued in our country for its characteristic flavor, which varies from region to region. It is mainly dependent on method of preparation. Goat milk is not considered suitablefor the manufacture of ghee(Arora and Singh, 1986). The average flavor score of ghee prepared from camel, cow and buffalo milk ghee was 33.73, 44.78 and 41.97 (out of 50) respectively (Parmar, 2013). Ghee prepared from cow milk and that from buffalo milk had pleasant flavor. However, ghee prepared from camel milk had an unpleasant flavor. Low flavor score in case of ghee from camel milk was attributed to its abnormal odor. The abnormal odor in ghee originated from abnormal odor associated with the camel milk itself. There are number of reports stating that camel milk has unpleasant odor and salty 
taste(Parmer, 2013; Mal and Pathak (2010); Hamid, 1993, Park and Haenlein, 2006)

The granules of buffalo ghee are irregular clusters, whereas those of cow ghee are smaller and made up of fine divergent mono crystals. Camel milk fat also has higher proportions of unsaturated fatty acids compared with other species, which may be the main reason for the waxy texture of camel milk fat (Park and Haenlein, 2006).In addition, the gheeobtained from goat milkwas found to be greasy.Parmar (2013) compared the textural attributes of ghee prepared from cow, buffalo and camel milk. The ghee prepared from cow milk had small to medium size grains uniformly distributed throughout the lot. The ghee prepared from buffalo milk had large grain size, whereasfrom camel milk had hard, greasy and waxy texture. Regional preference for ghee flavor and texture in India was reported by Rajorhia (1980) and given in table 2.

\section{Table 2: Regional preference for ghee flavour and texture in India}

\begin{tabular}{|c|c|c|}
\hline Region & $\begin{array}{l}\text { Physical } \\
\text { Character }\end{array}$ & Comments \\
\hline \multirow{2}{*}{$\begin{array}{l}\text { Northern } \\
\text { India }\end{array}$} & Flavor & Slightly acidic, mildly curdy \\
\hline & Texture & Fine- to medium-size grains (half to three quarters solid portion) \\
\hline \multirow{2}{*}{$\begin{array}{l}\text { Western } \\
\text { India }\end{array}$} & Flavor & Mildly curdy (very curdy in Saurashtra) \\
\hline & Texture & Coarse grains, i.e. size of 0.3 to $0.6 \mathrm{~mm}$ \\
\hline \multirow[t]{2}{*}{$\begin{array}{l}\text { Southern } \\
\text { India }\end{array}$} & Flavor & $\begin{array}{l}\text { Mild to highly cooked and aromatic, higher level of free fatty (butyric) acid, } \\
\text { preference for special herb flavours in Tamil Nadu and Karnataka }\end{array}$ \\
\hline & Texture & $\begin{array}{l}\text { Medium sized grains in Tamil Nadu, coarse grains in Andhra Pradesh and } \\
\text { Karnataka }\end{array}$ \\
\hline \multirow{2}{*}{$\begin{array}{l}\text { Eastern } \\
\text { India }\end{array}$} & Flavor & Slightly to definitely cooked flavour \\
\hline & Texture & Medium grains (one quarter liquid and three quarters solid) \\
\hline
\end{tabular}

Aroraand Singh (1986) studied the sensory aspects of ghee prepared from goat, buffalo and two types of mixed milk by threedifferent methods, namely, desi, creamery butterand direct-cream methods at aclarification temperature.Pure goat ghee was quiteacceptable ranking in "good" category butwas found tohave typical "goatyflavor".Theblending of goat milk with buffalo milk in $3: 1$ and 1:1 ratios improved the flavor quality.

\section{CONCLUSION}

Marked variations in physicochemical constants of ghee amongst species have been reported. This could be attributed to the differences in fatty acid composition of milk fat from these species. A comparison of nutritional aspects of ghee from various species revealed that ghee prepared from different species have their own distinctive characteristics which contribute greatly to their nutritional quality. A comparison of sensory aspects of ghee reveal that ghee prepared from cow and buffalo milk has pleasant flavor, whereas camel and goat milk ghee were unacceptable. Hence, more research is required to improve the acceptability of goat and camel milk ghee.

\section{REFERENCES}

1) Abdalla, M. (1994). Milk in the rural culture of contemporary Assyrians in the Middle-East. InMilk and Milk Products from Medieval to Modern Times, ed. P. Lysaght. Canongate Press, Edinburgh, pp. 27- 39.

2) Abou-Donia, S.A. and El-Agamy, S.I. (1993). Ghee. In Encyclopaedia of Food Science, Food Technology and Nutrition, Vol. 6, eds R. Macrae, R. K. Robinson and M. J. Sadler.Academic Press Ltd, London, pp. 3992-3994.

3) Achaya, K.T. (1997). Ghee, vanaspati and special fats in India. In Lipid Technologies and Applications, eds F. D. Gunstone and F. B. Padley. Marcel Dekker Inc., New York, pp. 369390. 
4) AGMARK. (1988). Ghee Grading and Marking Rules, 1938 (As amended in 1988), Agricultural Marketing Advisor (AMA), Directorate of Marketing and Inspection (DMI), Govt. of India, Faridabad (Haryana).

5) Ahmad, S., Anjum, F.M., Huma, N., Sameen, A. and Zahoor, T. (2013). Composition and physicchemical characteristics of buffalo milk with particular emphasis on lipids, proteins, minerals, enzymes and vitamins.J. Ani. Plant Sci., 23(1): 62-74.

6) Al-Khalifah, A. and Al-Kahtani, H. (1993). Composition of ghee (SamnBarri's) from cow's and sheep's milk. Food Chemistry, 46: 373-375.

7) Aneja, R.P. and Murthi, T.N. (1991). Beneficial effects of ghee. Nature, 35: 280-283.

8) Anjaneyulu, A.S.R., Lakshmanan, V. and Rao, K.V. (1985). Status of meat and milk production from Indian goats. J. Food Sci. Technol., 22: 151155.

9) Arora, K.L. and Singh, S. (1986). Effect of blending goat and buffalo milk on sensory characteristics of ghee. Indian J. Dairy Sci., 39(4): 488-490.

10) Bekele, E. and Kassaye, T. (1987). Traditional Borana milk processing efficient use of subtle factors needs further research work. Int. Live. Centre Africa, 6: 4-6.

11) Bharwade, M., Balakrishnan, S., Chaudhary, N. and Jain, A.K. (2017). Fatty Acid Profile and Physico-Chemical Characteristics of Milk Lipids of Kankrej Cow. Int. J. Curr. Microbiol. App. Sci., 6(8): 3035-3047.

12) Chin, S.F., Liu, W., Storkson, J.M., Ha, Y.L. and Pariza, M.W. (1992). Dietary sources of conjugated dienoicisomersof linoleic acid, a newly recognised class of anticarcinogens. J. Food Comp. Anal.,5(3): 185-197.

13) Codex Alimentarius. (1997). Draft revised standard for milk fat products (A-2), pp. 37-39.

14) FSSAI (2011). Food product standard and food additives. Ministry of health and family welfare, New Delhi. pp. 210-211.

15) Hamid, A.D. (1993). The Indigenous Fermented Foods of the Sudan: A Study in African Food and Nutrition. CAB International, Wallinford, UK.

16) Hazra, T., Sharma, V., Saha, P. and Parmar, M.P. (2017). Physico-chemical properties analysis based approaches to ascertain the purity of ghee. International Journal of Science, Environment and Technology, 6(1): 899-907.
17) IDF (1977). Anhydrous milkfat, anhydrous butteroil or anhydrous butterfat, butteroil or butterfat, ghee: standards of identity. Standard 68A. International Dairy Federation, Brussels, Belgium.

18) Iverson, J.L. and Sheppard, A.J. (1989). Detection of adulteration in cow, goat and sheep cheeses utilizing gas-liquid chromatographic fatty acid data. J. Dairy Sci., 72(7): 1707- 1713.

19) Jooyandeh, H. and Aberoumand, A. (2010). Physicochemical, Nutritional, Heat treatment effects and dairy products aspects of goat and sheep milk. World Applied Sci. J., 11(11): 13161322.

20) Kumar, A., Goyal, S. K., Kumar, V. and Kumar, L. (2016). Study on physico-chemical analysis of ghee. South Asian J. Food Technol. Environ., 2(3): 448-451.

21) Kumar, A., Upadhyay, N., Padghan, P.V., Gandhi, K., Lal, D and Sharma, V. (2015). Detection of vegetable oil and animal depot fat adulteration in anhydrous milk fat (ghee) using fatty acid composition. MOJ Food Processing and Technology, 1(3): 13-20.

22) Kumar, N. and Singhal, O.P. (1992). Effect of processing conditions on the oxidation of cholesterol in ghee. J.Sci. Agril., 58(2): 267-273.

23) Mahakalkar, A., Kashyap, P., Bawankar, R. and Hatwar, B. (2014). The versatility of cow ghee- An ayurveda perspective. American Journal of Drug Delivery and Therapeutics, 1(1): 28-34.

24) Mal, G. and Pathak, K.M.L. (2010). Camel milk and milk products. SMVS' Dairy year book. National Research Centre on Camel, Bikaner, Rajasthan, India. pp. 97-103.

25) Mohammadi, G. and Azizi, H. (2015). Effect of corn oil, olive oil, sheep's and cow's ghee on the expression of apoB protein in Syrian mice's intestine and liver. International Journal of Medical Laboratory, 2(1): 41-49.

26) Nath, B.S., Usha, M.A. and Ramamurthy, M.K. (1996). Effect of deep frying on cholesterol oxidation in ghee. J. Food Sci. Technol., 33: 425426.

27) Park, Y.W. and Haenlein, G.F.W. (2006). Handbook of Milk of Non-Bovine Mammals. Blackwell Publishing Ltd, Iowa, USA.

28) Parmar, N. (2013).Characterization of ghee prepared from camel milk and evaluation of its shelf life during storage. M. Tech thesis, Department of Dairy chemistry, Anand Agricultural University, Anand. 
29) Parodi, P.W. (2004). Milk fat in human nutrition. Aust. J. Dairy Technol., 59(1): 3-58.

30) Rajorhia, G.S. (1980). Advances in the preservation of ghee and regional preferences for quality. Indian Dairyman, 32: 745-750.

31) Rajorhia, G.S. (1993). Ghee. In Encyclopaedia of Food Science, Food Technology and Nutrition, Vol. 4, eds R. Macrae, R. K. Robinson and M. J. Sadler. Academic Press Ltd, London, pp. 21862192.

32) Ramesh, B. and Bindal, M.P. (1987). Influence of fatty acid composition on softening point and melting point of cow, buffalo and goat ghee. Indian J. Dairy Sci., 40(1): 94-97.

33) Raynal-Ljutovaca, K., Lagriffoulb, G., Paccardb, P., Guillet I and Chilliardc, Y. (2008). Composition of goat and sheep milk products: An update. Small Ruminant Research, 79: 57-72.

34) Ruegg, M.W. and Farah, Z. (1991). Melting curves of camel milk fat. Milchwissensch. 46(6): 361-362.

35) Sharma, R.S. (1981). Ghee: a resume of recent researches. J. Food Sci. Technol., 18: 70-77.

36) Singh, I. and Gupta, M.P. (1982). Physicochemical characteristics of ghee prepared from goat milk. Asian J. Dairy Res., 1: 201-205.
37) Singh, S. and Ram, B.P. (1978). Effect of ripening of cream, manufacturing temperature and packaging materials on flavour and keeping quality of ghee. J. Food Sci. Tehnol., 15: 142-145.

38) Srinivasan, M.R. (1976). Ghee making in the tropical countries and possibilities of its industrial production. Indian Dairyman, 28: 279-281.

39) Sserunjogi, M.L. and Roger K.A. (1998). Current Knowledge of Ghee and Related Products. Int. Dairy J., 8(8):677-688.

40) Tamime, A.Y. (2009). Dairy Fats and Related Products. A John Wiley \& Sons, Ltd., Publication by Blackwell Publishing Ltd. pp. 126-128.

41) Urbach, G. and Gordon, M.H. (1994). Flavours derived from fats. Fats in Food Products, eds. Moran, D. P. J. and Rajah, K. K. Blackie Academic and Professional, London, pp. 347-405.

42) Wayual, F.O., Karanja, P.N. and Adongol, A. (2006). Fatty acid compositions of Somali ghee made from goat's and cow's milk in Mandera, north eastern Kenya. Department of Food Science and Postharvest Technology, KARI, Marsabit, Kenya. 